\title{
PENGARUH KESESUAIAN KOMPENSASI DAN KULTUR ORGANISASI TERHADAP PERSEPSI PEGAWAI ATAS FRAUD DI INSTANSI PEMERINTAHAN KOTA MANADO
}

\author{
Jecklein $^{1}$, Lintje Kalangi ${ }^{2}$, Stanley Kho Walandouw ${ }^{3}$ \\ 1,2,3 Jurusan Akuntansi, Fakultas Ekonomi dan Bisnis, Universitas Sam Ratulangi, Jl. Kampus Bahu, Manado, \\ 95115, Indonesia \\ E-mail : jeklin28@gmail.com
}

\begin{abstract}
This study aimed to explore the employee perceptions of fraud in government agencies and the factors that influence the occurrence of fraud. The variables used in this study are the compliance of compensation and culture of organization as independent variables and fraud in government agencies as the dependent variable. Samples used in this research as many as 60 respondents from government agencies in Manado, especially in the Regional Financial and Asset Management Agency and the Office of Public Works and Spatial Planning of the City of Manado. Sampling technique uses purposive sampling and data collection used questionnaires. The analysis in this study used multiple linear regression analysis with the help of SPSS version 23 application. The results showed that, there is no influence of the appropriateness of compensation by fraud in Manado City government agencies, and there is a significant negative effect on fraud in Manado City government agencies.
\end{abstract}

Keywords: compatibility compensation, organizational culture, fraud, government agencies

\section{PENDAHULUAN}

Fraud merupakan tindakan yang sengaja dilakukan oleh beberapa orang untuk mengambil keuntungan dan dapat merugikan orang lain dan negara. Hal ini biasanya terjadi karena adanya tekanan, kesempatan, dan pembenaran yang membuat seseorang atau kelompok melakukan tindakan kecurangan. Kecurangan dalam akuntansi biasanya terjadi pada kesalahan pencatatan akuntansiyang dapat menyebabkan salah saji material.

Kecurangan (fraud) pada umumnya terjadi di instansi pemerintahan, hal ini disebabkan karena struktur organisasi pada instansi pemerintahan cukup kompleks, sistem yang kurang memadai, dan adanya tekanan serta kesempatan yang tinggi. Salah satu jenis kecurangan yang paling sering terjadi di instansi pemerintahan adalah korupsi. Di Manado, terdapat kasus penyimpangan dan melibatkan pejabat daerah yang masih aktif. Menurut data dari Kantor Badan Kepegawaian Negara (BKN) Manado menyatakan bahwa ada sejumlah PNS yang masih aktif bekerja meski telah terbukti melakukan tindak korupsi pada tahun 2017 lalu. Kompensasi merupakan balas jasa yang diberikan kepada seseorang atas pekerjaan yang telah dilakukan dan diberikan secara periodik. Kesesuaian kompensasi di lingkungan pegawai pemerintahan diyakini dapat mengurangi terjadinya kecurangan. Kadangkala seseorang yang tidak merasa puas atas balas jasa yang diberikan kepada mereka menimbulkan niat dalam diri mereka untuk melakukan tindakan kecurangan.

Setiap organisasi memiliki aturan, begitu pula dengan kantor maupun dinas pemerintah memiliki kultur organisasi yang berbeda dengan dinas yang lain. Hal ini disebabkan setiap organisasi atau lembaga memiliki tujuan tertentu. Kultur organisasi merupakan persepsi bersama yang dianut oleh suatu kelompok dalam menyelesaikan segala masalah yang ada sehingga mendapatkan tujuan yang sama. Dengan adanya panutan dalam 
instansi pemerintahan, maka dapat mengurangi adanya tindak kecurangan karena setiap lembaga akan memberikan aturan atau nilai-nilai yang diyakini bersama untuk menjauhi halhal yang dapat merugikan orang banyak tapi menguntungkan diri sendiri.

\section{TINJAUAN PUSTAKA}

Konsep Akuntansi. Akuntansi pada dasarnya adalah suatu laporan yang memberikan hasil tentang informasi keuangan dalam sebuah entitas ataupun organisasi bisnis yang akan dimanfaatkan oleh pengguna secara umum masyarakat dan secara khusus para pengambil keputusan dalam organisasi atau perusahaan (Pontoh, 2013: 2).

Akuntansi Pemerintahan. Akuntansi pemerintah adalah proses pencatatan, pengklasifikasian, pengiktisaran suatu transaksi keuangan pemerintah yang berdasarkan pada standar pelaporan keuangan pemerintah serta segala penafsiran atas informasi keuangan. Menurut American Accounting Association menyatakan bahwa tujuan akuntansi sektor publik adalah pengendalian manajemen dan akuntabilitas (Mardiasmo: 2018).

Audit Sektor Publik. Audit sektor publik bertujuan untuk memeriksa kebenaran dari sebuah pelaporan yang telah dibuat dengan keadaan yang sesungguhnya terjadi dalam pelaksanaan tugas dan kegiatan dengan bertanggung jawab di instansi pemerintah yang sesuai dengan standar yang berlaku secara umum.

Fraud (Kecurangan). Kecurangan (fraud) adalah istilah umum yang dirancang oleh kepandaian manusia dan biasanya digunakan secara individual guna memperoleh keuntungan dengan tindakan yang salah (Albrecht et al, 2012: 6).

Klasifikasi Fraud. Secara umum klasifikasi fraud terbagi menjadi 3 bagian, yaitu penyimpangan aset (asset missappropriatioan), pernyataan palsu (fraudelent statements), dan korupsi (corruption) yang biasanya digambarkan dalam fraud tree, dimana klasifikasi menggambarkan kemungkinan kecurangan yang dilakukan oleh karyawan dalam suatu entitas yang memiliki cabang-cabang dalam hubungan kerja dengan ranting serta anak rantingnya.

Fraud Triangle Theory. Teori ini dicetuskan pertamakan kali oleh Donald R. Cressey pada tahun 1950 setelah melakukan penelitin untuk tesis doktornya. Dalam penelitian tersebut Cressey mengungkapkan ada 3 elemen yang membuat seseorang melakukan fraud, yaitu dorongan (pressures), peluang atau kesempatan (opportunity), dan rasionalisasi (rationalization).

Agency Theory. Jensen dan Meckling mengemukakan, hubungan keagenan adalah sebuah kerja sama antara satu orang atau lebih (prinsipal) dengan pihak kedua (agen) secara kontrak dalam melaksanakan suatu kegiatan untuk kepentingan pihak prinsipal. Permasalahan yang sering muncul dalam hubungan keagenan adalah adanya konflik kepentingan akibat ketidaksamaan tujuan antara agen dan prinsipal serta adanya asimetri informasi (Messier et al: 2017).

Fraud di Instansi Pemerintahan. Kecurangan (fraud) yang paling sering terjadi di sektor pemerintahan adalah korupsi. Dalam UU No. 20 Tahun 2001, korupsi merupakan segala tindakan yang melawan hukum dengan maksud untuk menguntungkan (memperkaya) diri sendiri, orang lain, atau yang dapat merugikan negara maupun perekonomian negara.

Kesesuaian Kompensasi. Kompensasi adalah kontra prestasi terhadap penggunaan tenaga atau jasa yang telah diberikan oleh tenaga kerja (Wibowo: 2014). Tujuan dengan adanya kompensasi ini adalah ikatan kerja sama, pengaruh serikat buruh, kepuasan kerja, pengadaan efektif, stabilitas karyawan, motivasi, disiplin, dan pengaruh pemerintah (Hasibuan: 2013).

Kultur Organisasi. Kultur organisasi atau biasa dikenal dengan budaya organisasi merupakan segala keyakinan bersama yang diambil dari falsafah dasar ataupun pola kebiasaan pendirinya dan kemudian berinteraksi menjadi norma-norma yang akan diginakan 
sebagai pedoman dalam berpikir dan bertindak guna tercapainya tujuan bersama (Umar: 2010).

Pengaruh Kesesuaian Kompensasi terhadap Persepsi pegawai atas Fraud di Intansi Pemerintahan. Berdasarkan teori keagenan bahwa untuk menjalankan sebuah kerja sama yang baik antara prinsipal dan agen, maka pemberian kompensasi harus memadai agar agen dapat bertindak sesuai dengan keinginan dari pihak prinsipal. Dengan adanya pemberian kompensasi ini diharapkan dapat mengurangi kecenderungan terjadinya seseorang dalam melakukan fraud. Mustikasari (2013) menyimpulkan bahwa adanya pengaruh negatif antara kesesuaian kompensasi terhadap persepsi pegawai atas fraud di sektor pemerintahan. Berdasarkan uraian tersebut, maka dirumuskan hipotesis pertama yaitu:

$\mathrm{H}_{1}$ : kesesuaian kompensasi berpengaruh terhadap persepsi pegawai atas fraud di instansi pemerintahan Kota Manado.

Pengaruh Kultur Organisasi terhadap Persepsi pegawai atas Fraud di Intansi Pemerintahan. Peran dari kultur organisasi sangat penting, karena dengan adanya kultur organisasi maka setiap anggota memiliki pedoman untuk melakukan tindakan. Kultur organisasi yang baik akan membangun komitmen pada setiap pribadi anggota untuk selalu mengedepankan pencapaian bersama dibandingkan kepentingan pribadi. Dengan adanya komitmen pada diri setiap pegawai maka dapat mengurangi terjadinya fraud di instansi pemerintahan. Hasil penelitian Sulistiyowati (2007) menunjukkan bahwa pandangan aparatur pemerintah daerah tentang korupsi dapat dipengaruhi oleh kultur organisasi . Berdasarkan uraian tersebut, maka dirumuskan hipotesis kedua yaitu:

$\mathrm{H}_{2}$ : kultur organisasi berpengaruh terhadap persepsi pegawai atas fraud di instansi pemerintahan Kota Manado.

\section{METODE PENELITIAN}

Jenis Penelitian. Penelitian yang digunakan oleh penulis dalam mengkaji pengaruh kesesuaian kompensasi dan kultur oranisasi terahadap fraud di instansi pemerintahan adalah jenis penelitian kuantitatif.

Populasi, Metode Sampling, dan Sampel. Populasi dalam penelitian ini adalah seluruh pegawai tetap (Aparat Sipil Negara) pada Badan Pengelola Keuangan dan Aset Daerah Kota Manado, dan Kantor Dinas Pekerjaan Umum dan Penataan Ruang Kota Manado. Pada penelitian ini penentuan sampel menggunakan nonprobability sampling yaitu dengan metode purposive sampling yang artinya penentuan sampel dilakukan berdasarkan kriteria yang telah ditetapkan oleh peneliti. Berikut kriteria yang telah ditentukan: responden merupakan pegawai tetap di kantor pemerintahan, responden minimal telah bekerja selama 2 tahun, responden tidak dibatasi oleh jabatan. Berdasarkan kriteria tersebut maka sampel dalam penelitian ini berjumlah sebanyak 60 orang.

Metode Analisis. Penelitian ini menggunakan analisis data regresi linier berganda (Multiple Regression Analysis) dengan bantuan program Statistical Product and Service Solution (SPSS) versi 23. Analisis ini dilakukan untuk mengetahui apakah variabel bebas berpengaruh terhadap variabel terikat dan sbserapa besar pengaruh variabel bebas terhadap variabel terikat. Adapun analisis data yang digunakan adalah analisis regresi linear berganda, yang diawali dengan uji kualitas data yang bertujuan untuk mengetahui ketepatan alat ukur dalam mengukur objek yang diteliti. Model analisis regresi memerlukan uji asumsi klasik, untuk menginterpretasikan data agar lebih relevan dalam menganalisis. Uji asumsi klasik yang digunakan adalah uji normalitas, uji multikolinearitas, dan uji heteroskedastisitas. 


\section{HASIL PENELITIAN DAN PEMBAHASAN}

\subsection{Hasil Penelitian}

\section{Uji kualitas data}

Uji Validitas. Dalam melakukan penelitian, kuesioner yang digunakan harus valid dengan menggunakan Pearson Correlation yaitu dengan cara menghitung setiap korelasi antara skor masing-masing pertanyaan dengan skor total. Dimana suatu kuesioner dikatakan valid jika tingkat signifikannya dibawah 0,05 dan sebaliknya (Ghozali: 2016).

Tabel 1. Hasil uji validitas kesesuaian kompensasi

\begin{tabular}{cccc}
\hline Nomor Pertanyaan & $\begin{array}{c}\text { Pearson } \\
\text { Correlation }\end{array}$ & Sig (2-Tailed) & $\mathbf{5 \%}$ \\
\hline 1 (X1Q1) & $0,675^{* *}$ & 0,000 & 0,05 \\
2(X1Q2) & $0,751^{* *}$ & 0,000 & 0,05 \\
3 (X1Q3) & $0,676^{* *}$ & 0,000 & 0,05 \\
4 (X1Q4) & $0,759^{* *}$ & 0,000 & 0,05 \\
5 (X1Q5) & $0,799^{* *}$ & 0,000 & 0,05 \\
\hline
\end{tabular}

Sumber: Data Diolah (2018)

Tabel 2. Hasil uji validitas kultur organisasi

\begin{tabular}{cccc}
\hline Nomor Pertanyaan & $\begin{array}{c}\text { Pearson } \\
\text { Correlation }\end{array}$ & Sig (2-Tailed) & $\mathbf{5 \%}$ \\
\hline 1 (X2Q1) & $0,781^{* *}$ & 0,000 & 0,05 \\
2(X2Q2) & $0,749^{* *}$ & 0,000 & 0,05 \\
3 (X2Q3) & $0,841^{* *}$ & 0,000 & 0,05 \\
4 (X2Q4) & $0,735^{* *}$ & 0,000 & 0,05 \\
5 (X2Q5) & $0,752^{* *}$ & 0,000 & 0,05 \\
\hline
\end{tabular}

Sumber: Data Diolah (2018)

Tabel 3. Hasil uji validitas fraud di instansi pemerintahan

\begin{tabular}{cccc}
\hline Nomor Pertanyaan & $\begin{array}{c}\text { Pearson } \\
\text { Correlation }\end{array}$ & Sig (2-Tailed) & $\mathbf{5 \%}$ \\
\hline 1 (YQ1) & $0,831^{* *}$ & 0,000 & 0,05 \\
2 (YQ2) & $0,880^{* *}$ & 0,000 & 0,05 \\
3 (YQ3) & $0,934^{* *}$ & 0,000 & 0,05 \\
4 (YQ4) & $0,913^{* *}$ & 0,000 & 0,05 \\
5 (YQ5) & $0,945^{* *}$ & 0,000 & 0,05 \\
6 (YQ6) & $0,868^{* *}$ & 0,000 & 0,05 \\
7 (YQ7) & $0,879^{* *}$ & 0,000 & 0,05 \\
8 (YQ8) & $0,881^{* *}$ & 0,000 & 0,05 \\
9 (YQ9) & $0,880^{* *}$ & 0,000 & 0,05 \\
\hline
\end{tabular}

Sumber: Data Diolah (2018)

Uji validitas diatas menunjukkan bahwa semua pertanyaan yang digunakan dalam penelitian ini untuk masing-masing variabel memiliki kriteria valid. Hal ini ditunjukkan dengan nilai signifikansi $<0,05$ sehingga semua pertanyaan tersebut dapat digunakan untuk mengukur masing-masing variabel.

Uji reabilitas. Uji reabilitas dilakukan dengan tujuan untuk menguji konsistensi dari instrumen atau kuesioner dalam penelitian. Uji reliabilitas dilakukan dengan cara menghitung 
koefisien cronbach alpha >0,70 maka dapat disimpulkan bahwa instrumen penelitian tersebut reliabel (Ghozali: 2016).

Tabel 4. Hasil uji reliabilitas

\begin{tabular}{clcc}
\hline No & \multicolumn{1}{c}{ Variabel } & Cronbach's Alpha & Keterangan \\
\hline 1 & Kesesuaian Kompensasi & 0,782 & Reliabel \\
2 & Kultur Organisasi & 0,814 & Reliabel \\
3 & Fraud di Sektor Pemerintahan & 0,967 & Reliabel \\
\hline
\end{tabular}

Sumber: Data Diolah (2018)

Berdasarkan tabel 4 diatas menunjukkan nilai cronbach's alpha atas semua variabel lebih besar dari 0,7. Dengan demikian, dapat disimpulkan bahwa seluruh pertanyaan dalam kuesioner reliabel artinya setiap item pertanyaan mampu memperoleh data yang konsisten atau jawaban yang diperoleh relatif sama dengan jawaban sebelumnya.

\section{Uji Asumsi Klasik}

Uji Multikolonieritas. Uji multikolonieritas dalam sebuah penelitian bertujuan untuk mendeteksi adanya gejala korelasi antara variabel independen, dengan cara melihat nilai uji tolerance dan nilai Variance Inflation Factors (VIF). Jika nilai VIF $<10$ dan nilai tolerance > 0,10 dapat dinyatakan bahwa tidak ada korelasi sempurna antara variabel independen (Ghozali, 2016).

Tabel 5. Hasil uji multikolonieritas

\begin{tabular}{llcc}
\hline & \multicolumn{1}{c}{ Model } & \multicolumn{2}{c}{ Collinearity Statistics } \\
\cline { 3 - 4 } & & Tolerance & VIF \\
\hline 1 & (Constant) & 0,728 & 1,374 \\
& Kesesuaian Kompensasi & 0,728 & 1,374 \\
& Kultur Organisasi & & \\
a. Dependent Variable: Fraud di Sektor Pemerintahan &
\end{tabular}

Sumber: Data Diolah (2018)

Pada tabel 5 diatas, menunjukkan hasil uji multikolonieritas dengan nilai tolerance dari setiap variabel independen $>0,10$ dan nilai VIF setiap variabel $<10$ sehingga dapat disimpulkan bahwa tidak terjadi multikolonieritas atau tidak adanya korelasi antara variabel bebas yang di uji dalam penelitian ini.

Uji Normalitas. Dasar pengambilan keputusan dalam menguji normalitas sebuah penelitian yaitu jika nilai signifikan > 0,05 maka dapat disimpulkan bahwa data tersebut berdistribusi normal dan sebaliknya (Ghozali: 2016). Untuk pengujian normalitas dalam penelitian ini menggunakan rumus Kolmogorov-Smirnov. Berdasarkan tabel 6 maka dapat dilihat nilai asymp. Sig 0,082 >0,05 sehingga dapat disimpulkan bahwa data tersebut terdistribusi normal. 
Tabel 6. Hasil uji normalitas

$\mathrm{N}$

\section{Unstandardized Residual}

Normal Parameters ${ }^{\mathrm{a}, \mathrm{b}}$

Mean

0,0000000

Std. Deviation

9,73307359

Most Extreme Differences

Absolute

0,107

Positive

0,102

Negative

Test Statistic

Asymp. Sig. (2-tailed)

$0,082^{\mathrm{c}}$

Sumber: Data Diolah (2018)

Uji Heteroskedastisitas. Uji Glesjer dan grafik Scatterplot digunakan untuk pengujian heteroskedastisitas, dimana uji heteroskedastisitas bermanfaat untuk mengetahui apakah terdapat ketidaksamaan varians dari residual pada sebuah model regresi dari satu pengamatan yang lain.

Tabel 7. Hasil Uji Heteroskedastisitas dengan Uji Glesjer

\begin{tabular}{ccr} 
Model & t & Sig. \\
\hline Kultur Organisasi & 1,708 & 0,093 \\
Kesesuaian Kompensasi & 1,524 & 0,133 \\
a. Dependent Variable: RES_2 & &
\end{tabular}

Sumber: Data Diolah (2018)

Pada tabel 7 menunjukkan bahwa probabilitas signifikan variabel kesesuaian kompensasi sebesar 0,133 dan variabel kultur organisasi sebesar 0,093. Dengan demikian variabel independen menunjukkan probabilitas signifikan di atas tingkat kepercayaan 0,05 sehingga dapat disimpulkan bahwa tidak terjadi masalah heteroskedastisitas.

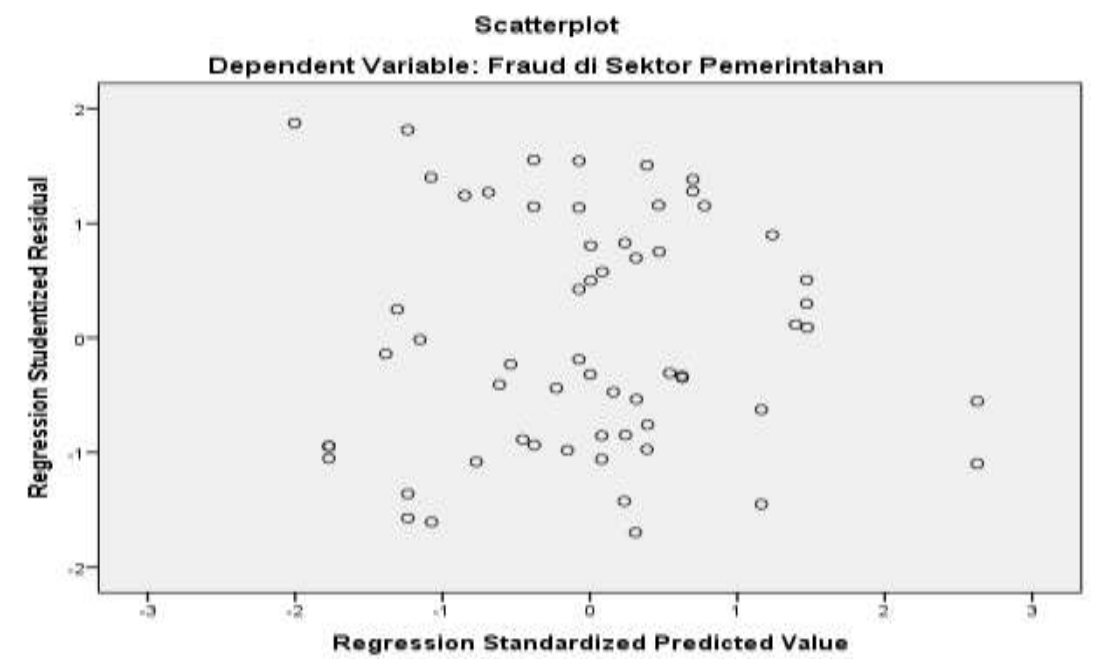

Gambar 1. Hasil uji heteroskedastisitas dengan scatterplot

Sumber: Data Diolah (2018) 
Berdasarkan pada gambar 1 diatas menunjukkan bahwa tidak terbentuknya pola tertentu yang jelas dan adanya penyebaran data, dan dibawah angka nol (0) pada sumbu Y maka disimpulkan bahwa tidak terdapat masalah heteroskedastisitas dalam penelitian ini.

Analisis Regregisi Linear. Pada penelitian ini model regresi berganda bertujuan untuk menguji pengaruh kesesuaian kompensasi $\left(\mathrm{X}_{1}\right)$ dan kultur organisasi $\left(\mathrm{X}_{2}\right)$ terhadap persepsi pegawai atas fraud di instansi pemerintahan (Y).

Tabel 8. Hasil analisis regresi berganda

\begin{tabular}{|c|c|c|c|c|c|}
\hline \multirow[b]{2}{*}{ Model } & \multicolumn{2}{|c|}{$\begin{array}{c}\text { Unstandardized } \\
\text { Coefficients }\end{array}$} & \multirow{2}{*}{$\begin{array}{c}\begin{array}{c}\text { Standardized } \\
\text { Coefficients }\end{array} \\
\text { Beta } \\
\end{array}$} & \multirow[b]{2}{*}{$\tau$} & \multirow[b]{2}{*}{ Sig. } \\
\hline & B & Std. Error & & & \\
\hline 16 (Constant) & 43,762 & 9,516 & & 4,599 & 0,000 \\
\hline $\begin{array}{l}\text { Kesesuaian } \\
\text { Kompensasi }\end{array}$ & 0,526 & 0,489 & 0,158 & 1,076 & 0,286 \\
\hline Kultur Organisasi & $-1,322$ & 0,502 & $-0,386$ & $-2,634$ & 0,011 \\
\hline
\end{tabular}

Sumber: Data Diolah (2018)

Berdasarkan tabel 8 diperoleh persamaan regresi berganda sebagai berikut:

$$
\mathrm{Y}=43,762+0,526 \mathrm{X}_{1}-1,322 \mathrm{X}_{2}+
$$

Dengan interpretasi sebagai berikut:

1. Koefisien model regresi memiliki nilai konstanta $(\alpha)$ sebesar 43,762 bernilai positif, berarti bahwa jika variabel independen konstan maka rata-rata fraud di sektor pemerintahan sebesar 43,762, dan nilai persepsi pegawai atas fraud di sektor pemerintahan semakin meningkat.

2. Koefisien regresi variabel $X_{1}$ memiliki nilai sebesar 0,526 dan bernilai positif, berarti kesesuaian kompensasi memiliki pengaruh positif terhadap persepsi pegawai atas fraud di instansi pemerintahan.

3. Koefisien regresi variabel $\mathrm{X}_{2}$ memiliki nilai sebesar 1,322 dan bernilai negatif, berarti kultur organisasi memiliki pengaruh secara negatif terhadap persepsi pegawai atas fraud di instansi pemerintahan.

Uji koefisien determinasi. Dalam pengujian koefisien determinasi (R square) dalam penelitian ini bertujuan untuk mengukur seberapa besar pengaruh variabel independen terhadap variabel independen (Ghozali: 2016).

Tabel 9. Hasil Uji Koefisien Determinasi $\left(\mathbf{R}^{2}\right)$

\begin{tabular}{ccccc}
\hline Model & $\mathbf{R}$ & \multicolumn{2}{c}{ R Square } \\
\hline 1 & & $0,332^{\mathrm{a}}$ & & 0,110
\end{tabular}

a. Predictors: (Constant), Kultur Organisasi, Kesesuaian Kompensasi

Sumber: Data Diolah (2018)

Pada tabel 9 diketahui bahwa nilai koefisien determinasi ( $R$ Square) sebesar $11 \%$. Hal ini menunjukkan bahwa $11 \%$ variabel dependen yaitu fraud di instansi pemerintahan dapat dipengaruhi oleh kedua variabel independen yaitu kultur organisasi dan kesesuaian kompensasi dan $89 \%$ dipengaruhi oleh variabel lainnya yang tidak diteliti dalam penelitian ini. Sebesar 33,2\% menunjukkan bahwa terdapat hubungan antara variabel dependen yaitu fraud di instansi pemerintahan dengan variabel independen yaitu kesesuaian kompensasi dan kultur organisasi. 
Uji Parsial (Uji t). Uji parsial atau biasa disebut dengan uji t berguna untuk mengetahui apakah dugaan sementara (hipotesis) dalam penelitian ini ditolak atau diterima. Caranya adalah dengan melihat apakah variabel independen secara individual dapat berpengaruh terhadap variabel dependen.

Tabel 10. Hasil uji parsial (Uji t)

\begin{tabular}{|c|c|c|c|c|c|}
\hline \multirow[b]{2}{*}{ Model } & \multicolumn{2}{|c|}{$\begin{array}{c}\text { Unstandardized } \\
\text { Coefficients }\end{array}$} & \multirow{2}{*}{$\begin{array}{c}\begin{array}{c}\text { Standardized } \\
\text { Coefficients }\end{array} \\
\text { Beta }\end{array}$} & \multirow[b]{2}{*}{ t } & \multirow[b]{2}{*}{ Sig. } \\
\hline & B & Std. Error & & & \\
\hline 1 (Constant) & 43,762 & 9,516 & & 4,599 & 0,000 \\
\hline $\begin{array}{l}\text { Kesesuaian } \\
\text { Kompensasi }\end{array}$ & 0,526 & 0,489 & 0,158 & 1,076 & 0,286 \\
\hline $\begin{array}{l}\text { Kultur Organisasi } \\
\text { a. Dependent Variab }\end{array}$ & $\begin{array}{l}-1,322 \\
\text { di Sekt }\end{array}$ & $\begin{array}{r}0,502 \\
\text { Pemerintahan }\end{array}$ & $-0,386$ & $-2,634$ & 0,011 \\
\hline
\end{tabular}

Berdasarkan tabel 10 nilai konstanta dari koefisien model regresi pada penelitian ini adalah sebesar 43,762 dengan nilai $t_{\text {hitung }}$ positif sebesar 4,599 dan dengan tingkat signifikan sebesar 0,000. Variabel kesesuaian kompensasi memiliki nilai $t_{\text {hitung }}$ sebesar 1,076 dengan tingkat signifikan sebesar 0,286 >0,05. Dengan demikian hipotesis pertama $\left(\mathrm{H}_{1}\right)$ ditolak. Hal ini menunjukkan bahwa secara parsial kesesuaian kompensasi tidak memiliki pengaruh terhadap persepsi pegawai atas fraud di instansi pemerintahan. Variabel kultur organisasi memiliki nilai $t_{\text {hitung }}$ sebesar -2,634 dengan tingkat signifikan 0,011 >0,05. Sehingga dugaan sementara $\left(\mathrm{H}_{2}\right)$ diterima, artinya kultur organisasi berpengaruh negatif secara signifikan terhadap pegawai atas fraud di instansi pemerintahan.

\subsection{Pembahasan}

Dalam penelitian ini hasil uji hipotesis pertama menunjukkan bahwa pada variabel kesesuaian kompensasi, memiliki nilai signifikan 0,286 > 0,05 sehingga variabel independen yaitu kesesuaian kompensasi tidak berpengaruh terhadap persepsi pegawai atas fraud di instansi pemerintahan. Dengan demikian penelitian ini memberikan bukti empiris bahwa fraud di instansi pemerintahan tidak dapat ditekan atau tidak dipengaruhi dengan adanya kesesuaian kompensasi. Hasil pengujian hipotesis kedua menunjukkan bahwa variabel kultur organisasi memiliki nilai signifikan $0,011<0,05$ dengan nilai $t_{\text {hitung }}$ sebesar 2,634. Sehingga variabel kultur organisasi berpengaruh negatif secara signifikan terhadap fraud di instansi pemerintahan.

\section{KESIMPULAN DAN SARAN}

\subsection{Kesimpulan} berikut:

Berdasarkan hasil penelitian dan pembahasan, maka peneliti menyimpulkan sebagai

1. Kesesuaian kompensasi $\left(\mathrm{X}_{1}\right)$ tidak berpengaruh terhadap fraud di instansi pemerintahan. Kesimpulan ini berdasarkan pada hasil analisis data yang menunjukkan bahwa nilai signifikan variabel kesesuaian kompensasi lebih besar dari nilai signifikan yang ditolerir yaitu 0,05. Berarti dengan adanya bukti empiris ini, maka kecenderungan terjadinya kecurangan ( fraud) di instansi pemerintahan tidak mampu dikurangi dengan adanya kesesuaian kompensasi.

2. Kultur organisasi $\left(\mathrm{X}_{2}\right)$ berpengaruh negatif secara signifikan terhadap fraud di instansi pemerintahan. Hal ini berdasarkan pada hasil analisis data yang menunjukkan bahwa nilai signifikan variabel kultur organisasi lebih kecil dari nilai signifikan yang ditolerir 
yaitu 0,05. Penelitian ini menunjukkan tingkat kecurangan (fraud) di instansi pemerintahan dapat diberkurang dengan adanya budaya organisasi yang etis.

\subsection{Saran}

Berdasarkan penelitian yang telah dilakukan, maka adapun saran yang dapat diberikan peneliti adalah sebagai berikut:

1. Para Aparatur Sipil Negara (ASN) untuk tetap menjaga integritas sebagai pelayan publik atau masyarakat sehingga dapat mengurangi terjadinya fraud di instansi pemerintahan. Dan selalu menanamkan rasa memiliki dan rasa bangga menjadi anggota dalam sebuah organisasi/lembaga pemerintahan.

2. Kepada calon peneliti selanjutnya diharapkan untuk menambah variabel-variabel independen selain kesesuaian kompensasi dan kultur organisasi, contohnya seperti penegakan hukum, komitmen organisasi, efektivitas sistem pengendalian internal, dan masih banyak variabel lain yang dapat mempengaruhi terjadinya kecurangan dalam instansi pemerintahan.

\section{DAFTAR PUSTAKA}

Albrecht, W. Steve et. all. 2012. Fraud Examination. South Western: Cengage Learning. USA.

Donald R. Cressey. 1979. The Theft of the Nation: The Structure and Operation of Organized Crime in America. New York: Harper and Row.

Ghozali, Iman. 2016. Aplikasi Analisis Multivariate dengan Program IBM SPSS 23. Semarang: Badan Penerbit Universitas Diponegoro.

Hasibuan S.P, Malayu. 2013. Manajemen Sumber Daya Manusia. Penerbit PT Bumi Aksara. Jakarta.

Mardiasmo. 2018. Akuntansi Sektor Publik. Penerbit Andi. Yogyakarta.

Mustikasari, Putri. 2013. Faktor-Faktor Yang Mempengaruhi Fraud di Sektor Pemerintahan Kabupaten Batang. Accounting Analysis Journal AAJ Vol. 2 No. 1.

Pontoh, Winston. 2013. Akuntansi Konsep dan Aplikasi. Penerbit: Halaman Moeka. Jakarta.

Republik Indonesia. Undang-Undang Nomor 20 Tahun 2001 tentang Pemberantasan Tindak Pidana Korupsi. Lembaran Negara Republik Indonesia Nomor 4150.

William, F. Messier et. all. 2014. Jasa Audit dan Assurance Pendekatan Sistematis. Salemba Empat: Jakarta. 